\title{
Citizenship and Exile: English Republicanism in a Transnational Context
}

Citoyenneté et exil : le républicanisme anglais dans un contexte transnational

\section{Gaby Mahlberg}

\section{(2) OpenEdition}

\section{Journals}

Electronic version

URL: http://journals.openedition.org/rfcb/787

DOI: $10.4000 / \mathrm{rfcb} .787$

ISSN: 2429-4373

Publisher

CRECIB - Centre de recherche et d'études en civilisation britannique

\section{Electronic reference}

Gaby Mahlberg, "Citizenship and Exile: English Republicanism in a Transnational Context », Revue Française de Civilisation Britannique [Online], XXI-1 | 2016, Online since 20 July 2016, connection on 30 April 2019. URL : http://journals.openedition.org/rfcb/787 ; DOI : 10.4000/rfcb.787

This text was automatically generated on 30 April 2019.

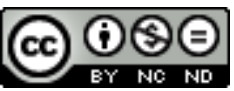

Revue française de civilisation britannique est mis à disposition selon les termes de la licence Creative Commons Attribution - Pas d'Utilisation Commerciale - Pas de Modification 4.0 International. 


\title{
Citizenship and Exile: English Republicanism in a Transnational Context
}

Citoyenneté et exil : le républicanisme anglais dans un contexte transnational

\author{
Gaby Mahlberg
}

\section{Introduction}

1 Seventeenth-century English republicans had several different yet related political and religious identities. On the one hand, republican thinkers modelled themselves on the western European classical humanist ideal of the citizen going back to Aristotle, stressing the centrality of political participation, which they linked with their more immediate demands for popular sovereignty, the rule of law and full accountability of political rulers in their own country. ${ }^{1}$ On the other hand, most English republicans were at the same time Reformed Protestants or Puritans, who saw themselves as members of God's invisible Church around the world. ${ }^{2}$ Their self-image was therefore at once political and religious, national and transnational. ${ }^{3}$

While civil and religious liberty had at least been partially achieved during the Civil War and Interregnum period of the 1640s and 1650s, the Restoration of the Stuart monarchy in 1660 meant that religious and political dissent was persecuted with renewed zeal, and republicans once again found themselves as the unwilling subjects of a tyrannical king. Consequently, many regicides, republicans and religious dissenters left England in search of physical safety as well as religious and political liberty.

3 This paper will assess the language and actions employed by English republicans, such as Edmund Ludlow and Algernon Sidney in European exile during the 1660s and 1670s, to conceptualise their transnational political and religious identity, their sense of citizenship, and their relationship to their home country. It will be argued that the republican exiles maintained strong links to England while abroad and continued to see 
themselves as political actors on behalf of their country and their 'cause', if not necessarily of a specific government. This independent sense of public duty also meant the pursuit of their aims did not prevent them from temporarily serving or submitting to different governments, or indeed considering military action against the government of their own country.

\section{Sidney and public service}

The $8^{\text {th }}$ May 1660 was a fateful day for many English republicans as the Convention Parliament proclaimed Charles II as the lawful monarch of England. With the consent of the elected representatives of the nation, the Stuarts were back on the English throne and the citizens of the English republic once again became the subjects of a monarchy. Many of those who had been politically active in the Commonwealth meanwhile distrusted the new regime and the provisions of the Act of Indemnity and Oblivion and either decided to leave the country or remain abroad to save their skin. ${ }^{4}$

The two individuals I will focus on in this article, Algernon Sidney and Edmund Ludlow, shared common experiences of flight, persecution and displacement, even though only Ludlow was a regicide. But both had been active in Civil War and Interregnum politics as soldiers and generals, MPs and Councillors of State, while Sidney had also served the Commonwealth as a diplomat. ${ }^{5}$ Their political identity was based on participation, loyalty to their country and their common 'cause' of liberty and republicanism.

English republicans defined the role of the citizen with Aristotle as that of an individual who participated "in the administration of justice, and in offices", i.e. as that of an active member of the political nation, endowed with political agency by the authorities of the state. While they used the term 'citizen' itself primarily with reference to the Greek and Roman city-states, they nevertheless shared its notion of public duty, virtue and merit in their own political context for the members of the English polity. ${ }^{7}$ All citizens were equal in principle, but special merit and virtue could advance an individual to leadership. ${ }^{8}$ Citizens could therefore act either in a private or in a public capacity, if they acted in a leading role that elevated them over their fellow citizens.

While the change of regime in the spring of 1660 changed their employment and personal situation, it did not change the republicans' sense of public duty. In fact, their sense of themselves as political actors was to an extent independent of the government they served, which agrees with the observations made by Patrick Collinson, Steve Hindle, Mark Goldie and others on the compatibility of an ethos of citizenship with monarchical structures. ${ }^{9}$ This is most obvious in the letter Algernon Sidney sent to his father Robert, earl of Leicester from Stockholm on 27 June 1660 after receiving "the Newes of the Kings Entry into London". ${ }^{10}$ Sidney had been away negotiating a peace between Sweden and Denmark on behalf of the English Commonwealth to secure trading interests in the Baltic Sound, ${ }^{11}$ when he heard of the Restoration of the Stuarts, and for a while was seriously considering what to do and whether or not to continue in his current position.

I ... am absolutely uncertaine what Course I shall take ... I would be unwilling to stay in a Place, wheare I have bin long under a character that rendred me not inconsiderable, now that my Powers are extinguished, and I am left in a private Condition ... . On the other Side, I knowe the Advantage it would be to me, to have newe Orders from the King, and am unwilling to put my self out of a Condition of 
receaving them, unlesse I am theareunto necessitated, or know that none will be sent. $^{12}$

thus also stayed because he was first and foremost, as he put it, a "Servant to my Country", for whom public duty was not necessarily bound to a specific government. ${ }^{15} \mathrm{He}$ also appeared to have sufficient "Respect" for Charles II, who had been welcomed back into England as king, to wait for his instructions. When no instructions from the new regime were forthcoming, Sidney took his father's advice to move on to Hamburg "and from thence into Holland, or somme Place in Germany, wheare I may lye still a While, and see what is to be expected for me." ${ }^{16}$ For the republicans, it seems, it was all 'wait and see'.

10 A little later, at the end of November and by then safely settled in Rome, Sidney seemed relieved that he had listened to his father and his friends, who had advised him "to keepe out of England for a While", judging "by the Usage my Companions have already received". ${ }^{17}$ This of course alluded to the fate of the ten regicides who had been exempted from the Act of Indemnity and Oblivion and sentenced to death to be publicly hanged, drawn and quartered at Tyburn in October. ${ }^{18}$ These included Thomas Scott, with whom Sidney had worked on the Council of State and in the area of foreign affairs, ${ }^{19}$ while Sidney's good friend Sir Henry Vane the younger was likewise exempted from the Indemnity and Oblivion Act to be executed two years later..$^{20}$ exile rejecting the monarchy - at least not yet. The most severe punishment for Sidney was to remain excluded from public office and from participation in the politics of his home country. ${ }^{21}$ This rejection might have hardened him towards the government of Charles II and contributed to his future plans of a foreign invasion of England with exile support. While Sidney decided to stay abroad for his own personal safety and was travelling via Germany to Italy, the regicide Edmund Ludlow was making his escape to Switzerland to the Calvinist capital of Geneva. ${ }^{22}$

\section{Ludlow's providential republicanism}

Ludlow's political identity was closely bound up with his religious faith and belief in divine providence, which had carried him to Geneva. In the manuscript of his memoirs, ${ }^{23}$ he described himself and his fellow exiles as "sufferers for the Cause of Christ, \& the Libertyes of our Country" ${ }^{24}$ while his rejection of the Stuart monarchy was primarily based on the King's usurpation of divine rule, as only God could claim to be a legitimate monarch. ${ }^{25}$ Unlike Sidney, Ludlow was from the start openly hostile to Charles II, whom he frequently referred to in his draft memoirs as a "tyrant" and as the "present Usurper". ${ }^{26}$ Conversely, the friendly welcome received by the exiles in Switzerland "layd a great Obligation on us to 
bless the Lord, who had raysed up so many to favour us \& our righteous Cause in a forreigne \& strandge Land." ${ }^{27}$

When the regicides John Barkstead, Miles Corbet and John Okey were extradited from the Netherlands under Johan de Witt's government in $1662,{ }^{28}$ however, Ludlow feared that he and his fellow exiles John Lisle and William Cawley might soon experience the same fate, unless the Genevan authorities formalised their protection. When Geneva failed to do so, the little group sought help from the notorious Jesuit convert Jean de Labadie and the chief minister of Bern Johann Heinrich Hummel, both of whom had long-standing contacts to the various Interregnum regimes. ${ }^{29}$ With the support of these illustrious preachers the exiles then moved to the canton of Bern, were assigned religious refugee status, and gathered a small community of exiles around them..$^{30}$ But even after their removal to Vevey, Ludlow never felt entirely safe from strangers and potential assassins sent across the French border by Charles II's sister, the Duchess of Anjou. ${ }^{31}$

\section{Fear of assassins}

For the same reason, Sidney kept a distance from his countrymen in exile and was alert to any rumours about him. He wrote to his father from Rome that "the Court heare" had ordered the Internuntio in Flanders to make enquiries about his "Birth, Person, and Quality ", and that information had been given that

I was ever found to be violent against Monarchy, a Friend unto Roman Catholiques, one that in our last Troubles, meddled little with private Businesse, and that had made my Fortune, by the Warre, with some other Things like unto theis, Part true, and Part false; but none that I can learne which doth me any Prejudice. They weare put upon this Enquiry, by the foolish prating of some Priests, who spoke of me, as the only Enimy the King had left, and that I being taken away, his Majesty might reagne in Quiet. ${ }^{32}$

While Sidney lightly dismissed these rumours, ${ }^{33}$ he nevertheless seemed relieved to see the strangers leave town after Holy Week, as he "never found any Inconvenience heare, but by theire Company, and Neighbourhood." ${ }^{34}$ Or, as he put it in an earlier letter to his father, he felt 'well enough at Ease' in Rome "unlesse somme Boddy from the Court of England doth think it worth theire Paines to disturbe me." 35

With a permanent threat of persecution and assassination emanating from the English government and its allies, the exiles were at times helpless and bitter towards their own country. While Sidney claimed he was not shaken by the "Misfortunes", into which he had fallen "by the Destruction of our Party" ${ }^{36}$ in England, he nevertheless reported at times feeling desperate or "naked, alone, and without Help in the open Sea." ${ }^{37}$ In particular he found it shameful to live on a shoestring budget ${ }^{38}$ and

in a Place farre from Home, wheare noe Assistance can possibly be expected, and wheare I am knowne to be of a Quality, which makes all lowed and meane Wayes of Living shamefull and detestable. ${ }^{39}$

Sidney was painfully aware of the mismatch between his "Quality" and station in life and his poor circumstances, that not only forced him to remain abroad, but to live a life well below his aristocratic upbringing. He also felt rather snubbed by the restored monarchy, which deprived him both of his political role and social status.

Meanwhile in England, the situation of political and religious dissenters was worsening day by day, with dissenters filling the prisons and a new set of penal laws established by 
the so-called Clarendon Code..$^{40}$ With dissatisfaction growing among the opposition against the Stuarts at home and abroad, Sidney had found the patriotic task he had been waiting for. Over the next couple of years we find him criss-crossing Europe in an attempt to raise an army to invade England from abroad to restore the Long Parliament and republican rule..$^{41}$ And for this task he was trying to enlist the help of Ludlow.

\section{The Anglo-Dutch War and the Sidney Plot of 1665-6}

March 1665 gave the republicans new hope for a restoration of the Commonwealth. English republicans saw the Protestant and republican Dutch as natural allies, as both were enemies of Charles II, while also sharing a religious and political outlook. While many historians - doubtless with a view towards the Glorious Revolution - have exaggerated the friendly disposition of the Grand Pensionary Johan De Witt towards the exile community, ${ }^{44}$ however, Sidney's contemporary allies treated the whole situation with more caution. against Charles Steward", Ludlow's fellow exile in Vevey, William Say, made his way to the United Provinces..$^{45}$ He met with William Nieuwpoort, the former Dutch ambassador to the Rump, who promised the exiles a fleet of 30,000 men at their disposal and urged them to set up a council of English republicans and Dutch representatives to discuss further moves. ${ }^{46}$ The plan was to free Major General John Lambert from prison in Guernsey and to put him and Ludlow in charge of the troops ${ }^{47}$ Rebels in England and Scotland were allegedly "ready to rise at 5 days warning", and "a very considerable Body" of them was "ready to draw together in the North, and ... West of England". The exiles were asking for 4,000 foot soldiers to land at Newcastle which would be "delivered to them". ${ }^{48}$

23 As their plans developed, Sidney increasingly put pressure on Ludlow to come to their aid, even accusing him of disowning "the publique Cause" if he did not, and of jeopardising their plans by his absence..$^{49}$ But Ludlow had serious reservations about the trustworthiness of the Dutch, who "prefer[red] their Trade before the honour of God \& Christ". 
${ }^{50}$ His particular bugbear was the extradition of the regicides three years earlier, while he was also unwilling to jeopardise his position in Switzerland, as the authorities of Bern had advised him to stay away from anything that might upset relations between the Swiss and Stuart England. ${ }^{51}$

Despite these concerns Sidney personally travelled to The Hague to negotiate with De Witt. But talks came soon to a halt. Be it because of Ludlow's unwillingness to lead the military operation or a lack of trust in Sidney's ability, De Witt seemed neither convinced by the feasibility or even desirability of such a plot. ${ }^{52}$ After all, during the Commonwealth England had risen to become a genuine competitor at sea, while the Restoration monarchy seemed negligible in comparison. By the end of 1665 , the plotters had removed their headquarters to Rotterdam, but, amid divisions between the exiles, not much else had happened.

When Louis XIV entered into an anti-English alliance with the States General and in January 1666 also declared war, the plot was revived, and Sidney and Ludlow were invited to Paris for talks. But Ludlow refused to join a conspiracy he considered doomed from the start, despite demands from the exile community to follow "the Lords Call to a glorious worke, wherein the Interest of the Lords people throughout the world was concerned", ${ }^{53}$ with Say urging Ludlow that "all there [in Rotterdam]" were ready to join him, but if he refused "not a man would stir". ${ }^{54}$

Ludlow conceded he might be able to collaborate with the Dutch if they acknowledged fault in the extradition of Barkstead, Corbet and Okey, but there was no way he would ever trust the French. He suspected them behind the hired assassins who had followed the exiles to Switzerland. ${ }^{55}$ Moreover, France was the home of absolutism, Catholicism and everything the exiles hated and despised. Collaboration with the French made the plot unacceptable both to Ludlow and some of the other exiles. So Sidney travelled to Paris without him. ${ }^{56}$

According to the Memoirs of Louis XIV, Sidney asked for 100,000 écus ${ }^{57}$ to produce a great uprising in England. Reluctant to risk such an amount "on the word of a fugitive", however, the King only committed 20,000 and promised more later if he could see results. ${ }^{58} \mathrm{But}$ Sidney had already lost the backing of the majority of the exiles. With support waning on all sides, Sidney finally decided to go it alone. He "volunteered to command the invasion [of England] directly from Paris leading the French troops" himself, thus, as Jonathan Scott put it, committing "political suicide". 59

The plot finally failed over the mutual distrust of the different parties in an unlikely and rather unhappy alliance, while the exile community split over the best plan of action. But we certainly cannot blame them for want of trying.

\section{Conclusion}

As I hope to have shown, the republican exiles who either failed to return to England after the Restoration or had to leave England for fear of their lives never broke with their home country or their public role. Despite the return of the monarchy, Sidney and Ludlow were aware of their position in society and the political realm, even though their focus might have shifted from a role of representatives of their nation to that of underground activists. 

century intellectual history, republicanism and utopianism. She was a Senior Lecturer in Early Modern History at Northumbria University in Newcastle, UK, before leaving in August 2015 to work as an Editor for the German news agency dpa in Berlin. She is the author of Henry Neville and English Republican Culture in the Seventeenth Century (Manchester, MUP, 2009), and has co-edited with Dirk Wiemann, European Contexts for English Republicanism (Farnham, Ashgate, 2013) and Perspectives on English Revolutionary Republicanism (Farnham, Ashgate, 2014). Most recently she co-edited with Cesare Cuttica, Patriarchal Moments (London, Bloomsbury, 2016).

\title{
BIBLIOGRAPHY
}

\author{
Archival Sources
}

Bodleian Library, Oxford, "A voyce from the watch tower", Oxford, Bodleian Library, MS

Eng.hist.c. 487

Staatsarchiv Bern, Raths-Manual der Stadt Bern, A II 454, vol. 143 (27 January 1662 to 7 June 1662).

Printed Primary Sources

Aristotle, The Politics and The Constitution of Athens, ed. Stephen Everson, Cambridge, Cambridge University Press, 1996.

Collins, Arthur, Letters and memorials of state in the reigns of Queen Mary, Queen Elizabeth, King James, King Charles the First, part of the reign of King Charles the Second, and Oliver's usurpation. Written and collected by Sir Henry Sydney ... Sir Philip Sydney and his brother Sir Robert Sydney... Robert, the second Earl of Leicester... Philip, Lord Viscount Lisle ... and of his brother, Colonel Algernon Sydney. Faithfully transcribed from the originals at Penshurst Place in Kent, the Seat of the Earls of Leicester, and from His Majesty's Office of Papers and Records for business of state: together with letters of the other ministers of 
state, with whom they held a correspondence: whereunto is added genealogical and historical observations: also memoirs of the lives and actions of the Sydneys, and their noble ancestors the Dudleys, Grey, Talbot, Beauchamp, Berkley and Lisle; and a defence of Robert Dudley, Earl of Leicester, wrote by Sir Philip Sydney..., 2 vols, London, printed for T. Osborne, in Gray's-Inn. MDCCXLVI. [1746].

Louis XIV, Mémoires pour les années 1661 et 1666, ed. J. Lognon, Paris, 1923.

Ludlow, Edmund, A voyce from the watch tower: part five: 1660-1662, ed. A.B. Worden, London, 1978.

Sidney, Algernon, Court Maxims, ed. Hans W. Blom, Eco Haitsma Mulier, Ronald Janse, Cambridge, Cambridge University Press, 1996.

---. Discourses concerning government, ed. Thomas G. West, Indianapolis (IN), Liberty Fund, 1996.

The speeches and prayers of some of the late king's judges, viz. Major General Harison, Octob. 13....

Together with severall occasionall speeches and passages in their Imprisonment till they came to the place of execution. Faithfully and impartially collected for further satisfaction. Heb. 11.4 And by it he being dead, yet speaketh. n.p., Printed Anno Dom. 1660.

Secondary Works

Borot, Luc, "Subject and Citizen: The Ambiguity of the Political Self in the Early Modern English Commonwealth" (present journal issue).

Catterall, Ralph C.H., "Sir George Downing and the Regicides", American Historical Review 17 (1912), pp. 268-289.

Coffey, John, "Puritanism and Liberty Revisited: the Case for Toleration in the English Revolution", Historical Journal 41: 4 (1998), pp. 961-985.

Collinson, Patrick, "The Monarchical Republic of Queen Elizabeth I", Bulletin of the John Rylands University Library of Manchester 69 (1987), pp. 394-424.

---, De republica Anglorum: or, history with the politics put back, Cambridge, 1990.

Davis, J.C., "Religion and the Struggle for Freedom in the English Revolution", Historical Journal 35:3 (1992), pp. 507-530.

Firth, C.H., "Ludlow, Edmund (1616/17-1692)", rev. Blair Worden, Oxford Dictionary of National Biography, Oxford University Press, 2004; online edn, May 2006 [http://www.oxforddnb.com/ view/article/17161, accessed 25 April 2014].

Goldie, Mark, "The unacknowledged republic: officeholding in early modern England" in Tim Harris (ed.), The Politics of the Excluded, c. 1500-1850 (Basingstoke, Palgrave, 2001), pp. 153-94.

Harris, Tim, Restoration: Charles II and His Kingdoms, 1660-1685 (London, Allen Lane, 2005).

Held, David, "Cosmopolitanism, democracy and the global order" in Maria Roviso and Magdalena Nowicka (eds), The Ashgate Research Companion to Cosmopolitanism (Farnham, Ashgate, 2011), pp. 163-77.

Hindle, Steve, "Hierarchy and Community in the Elizabethan Parish: The Swallowfield Articles of 1596", Historical Journal 42 (1999), pp. 835-51.

Holmes, Clive, "John Lisle, Lord Commissioner of the Great Seal, and the Last Months of the Cromwellian Protectorate”, English Historical Review 122 (2007), pp. 918-36.

Hugli, Jean, “Les 'régicides' anglais et l'assassinat du chancelier Lisle (1664)”, in Grandes heures de Lausanne (1041-1797): Ouvrage orné de 8 hors-texte et d'une vignette de couverture (Lausanne, 1967), chapter 7. 
---, “Un drame à Lausanne en 1664”, Rendez-vouz: Revue du Léman 10 (October, 1948), no pagination.

Hull, William, Benjamin Furly and Quakerism in Rotterdam (Lancaster, Lancaster Press, 1941), pp. 77-82.

Hutton, Sarah (ed.), Benjamin Furly 1646-1714: a Quaker Merchant and his Milieu (Firenze: Olschki, 2007).

Mahlberg, Gaby, “Les juges jugez, se justifiants (1663) and Edmund Ludlow's Protestant Network in Seventeenth-Century Switzerland”, Historical Journal 58:2 (2014), pp.1-28.

Ngai, Mae M., "Promises and Perils of Transnational History," Perspectives Online 50:9, December 2012, http://www.historians.org/perspectives/issues/2012/1212/Promises-and-Perils-ofTransnational-History.cfm consulted 7 September 2013.

Peltonen, Markku, Classical Humanism and Republicanism in English Political Thought, 1570-1640 (Cambridge, Cambridge University Press, 2004).

Rahe, Paul A., Republics Ancient and Modern, 3 vols (Chapel Hill, NC \& London, University of North Carolina Press, 1994).

Scott, Jonathan, Commonwealth Principles: Republican Writing of the English Revolution (Cambridge, Cambridge University Press, 2007).

---, Algernon Sidney and the English Republic 1623-167 (Cambridge, Cambridge University Press, 1988).

Simonutti, Luisa, "English guests at 'De Lantaarn'. Sidney, Penn, Locke, Toland and Shaftesbury” in Sarah Hutton (ed.), Benjamin Furly 1646-1714: a Quaker Merchant and his Milieu (Firenze, Olschki, 2007), pp. 31-66.

Van Santvoord, G(eorge), Life of Algernon Sidney: with sketches of some of his contemporaries and extracts from his correspondence and political writings, $3^{\text {rd }}$ ed. (New York, Charles Scribner, 1858).

Winship, Michael, “Algernon Sidney's Calvinist Republicanism”, Journal of British Studies 49:4 (2010), pp. 753-773.

Worden, Blair. "Whig History and Puritan Politics: The Memoirs of Edmund Ludlow revisited", Historical Research 75 (2002), pp. 209-37.

---. "Providence and Politics in Cromwellian England", Past and Present 109 (1985), pp. 55-99.

---. "Classical republicanism and the Puritan Revolution" in Hugh Lloyd-Jones, Valery Pearl and Blair Worden (eds), History and Imagination: Essays in Honour of H.R. Trevor-Roper (London, Duckworth, 1981), pp. 182-200.

\section{NOTES}

1. * I would like to thank the organisers of the conference «La conception britannique de la citoyenneté: histoire, evolutions, transferts "/ "The British Conception of Citizenship: History, Changes and Transfers" at the Université de Toulouse II - Le Mirail, Nathalie Duclos and Vincent Latour, as well as Myriam-Isabelle Ducrocq for inviting me to present this paper, and the panel chair Xavier Cervantes and the audience for their helpful comments. I am also grateful to Delphine Doucet for helping me with the translation of the abstract into French.

The key work is Aristotle's Politics. For a modern edition see Aristotle, The Politics and The Constitution of Athens, ed. Stephen Everson (Cambridge, Cambridge University Press, 1996); see 
also Markku Peltonen, Classical Humanism and Republicanism in English Political Thought, 1570-1640 (Cambridge, Cambridge University Press, 2004); and Jonathan Scott, Commonwealth Principles: Republican Writing of the English Revolution (Cambridge, Cambridge University Press, 2007).

2. John Coffey, "Puritanism and Liberty Revisited: the Case for Toleration in the English Revolution", Historical Journal 41:4 (1998), pp. 961-985; J.C. Davis, "Religion and the Struggle for Freedom in the English Revolution", Historical Journal, 35:3 (1992), pp. 507-530; Blair Worden, "Classical republicanism and the Puritan Revolution" in Hugh Lloyd-Jones, Valery Pearl and Blair Worden (eds), History and Imagination: Essays in Honour of H.R. Trevor-Roper (London, Duckworth, 1981), pp. 182-200; the same, "Providence and Politics in Cromwellian England", Past and Present 109 (1985), pp. 55-99. Sometimes a distinction is drawn between "religious" and "secular"/"constitutional" republicanism, whereas I would argue that elements of both can be found in all seventeenth-century English republicans to varying degrees.

3. I use the buzzword "transnational" as a conscious anachronism for polemical purposes to draw attention to the narrow insularity of much English historiography which says more about the way in which modern historians work than about the nature of early modern political thought and activism. For the early modern period, an era that predates the "nation state", terms like "transterritorial" or "transcultural" might be more appropriate. However, the use of "transnational" has been established to describe a history that crosses a variety of borders. Cf. Mae M. Ngai, "Promises and Perils of Transnational History", Perspectives Online 50:9 (December 2012), http://www.historians.org/perspectives/issues/2012/1212/Promises-and-Perils-ofTransnational-History.cfm consulted 7 September 2013.

4. For an excellent recent summary of Restoration politics, see Tim Harris, Restoration: Charles II and His Kingdoms, 1660-1685 (London, Allen Lane, 2005).

5. Jonathan Scott, Algernon Sidney and the English republic 1623-1677 (Cambridge, Cambridge University Press, 1988), "Part Two: War and Politics", pp. 75-140 passim, and pp. 124ff; C. H. Firth, "Ludlow, Edmund (1616/17-1692)", rev. Blair Worden, Oxford Dictionary of National Biography (Oxford, Oxford University Press, 2004); online edn, May 2006 [http://www.oxforddnb.com/ view/article/17161 consulted 25 April 2014].

6. Aristotle, Politics, p. 62.

7. E.g. Sidney in the Court Maxims stresses "virtue" and "piety" (p. 2) as key characteristics of good subject-citizens and courtiers. The "seeds of virtue" (p. 3) in a courtier show the quality of his standing, while "virtue" should be "cherished" (p. 7). See Algernon Sidney, Court Maxims, ed. Hans W. Blom, Eco Haitsma Mulier, Ronald Janse (Cambridge, Cambridge University Press, 1996).

8. See Algernon Sidney, Discourses concerning government, ed. Thomas G. West (Indianapolis (IN), Liberty Fund, 1996), II:1, pp. 79-80, referring to Aristotle's Politics.

9. For a compatibility of civic duty with a monarchical framework, see Patrick Collinson, "The monarchical republic of Queen Elizabeth I", Bulletin of the John Rylands University Library of Manchester 69 (1987), pp. 394-424, and the same, De republica Anglorum: or, history with the politics put back (Cambridge, 1990); Steve Hindle, "Hierarchy and Community in the Elizabethan Parish: The Swallowfield Articles of 1596", Historical Journal 42 (1999), pp. 835-51; Mark Goldie, "The unacknowledged republic: officeholding in early modern England" in Tim Harris (ed.), The Politics of the Excluded, c. 1500-1850 (Basingstoke, 2001), pp. 153-94. See also Peltonen, Classical Humanism and Republicanism and Luc Borot's article "Subject and Citizen: The Ambiguity of the Political Self in the Early Modern English Commonwealth" in the present journal issue.

10. Algernon Sidney from Stockholm to Robert earl of Leicester, 27 June 1660, in Arthur Collins, Letters and memorials of state in the reigns of Queen Mary, Queen Elizabeth, King James, King Charles the First, part of the reign of King Charles the Second, and Oliver's usurpation. Written and collected by Sir Henry Sydney ... Sir Philip Sydney and his brother Sir Robert Sydney... Robert, the second Earl of Leicester... Philip, Lord Viscount Lisle ... and of his brother, Colonel Algernon Sydney. Faithfully transcribed from the originals at Penshurst Place in Kent, the Seat of the Earls of Leicester, and from His Majesty's Office of 
Papers and Records for business of state: together with letters of the other ministers of state, with whom they held a correspondence: whereunto is added genealogical and historical observations: also memoirs of the lives and actions of the Sydneys, and their noble ancestors the Dudleys, Grey, Talbot, Beauchamp, Berkley and Lisle; and a defence of Robert Dudley, Earl of Leicester, wrote by Sir Philip Sydney..., 2 vols (London, printed for T. Osborne, in Gray's-Inn. MDCCXLVI. [1746]), vol. II, pp. 690-1.

11. Scott, Algernon Sidney and the English Republic, p. 125.

12. Ibid., p. 690 .

13. Algernon Sidney from Copenhagen to Robert earl of Leicester, 14 July 1660, in Collins, Letters and memorials of state, pp. 691-4, p. 691.

14. Ibid.

15. Ibid., p. 694.

16. Ibid., p. 691.

17. Algernon Sidney to Robert earl of Leicester from Rome, 19/29 November 1660, in Collins, Letters and memorials of state, pp. 700-1.

18. See The speeches and prayers of some of the late king's judges, viz. Major General Harison, Octob. 13.... Together with severall occasionall speeches and passages in their Imprisonment till they came to the place of execution. Faithfully and impartially collected for further satisfaction. Heb. 11.4 And by it he being dead, yet speaketh. n.p. (Printed Anno Dom. 1660).

19. Scott, Algernon Sidney and the English Republic, p. 50, p. 101.

20. Ibid., pp. $94 \mathrm{ff}$.

21. Cf. Paul A. Rahe, 'Introduction' to vol. I of Republics ancient and modern (Chapel Hill (NC) and London, University of North Carolina Press, 1994), pp. 22-3 on the Greek practice of ostracism.

22. Edmund Ludlow, A voyce from the watch tower: part five: 1660-1662, ed. A.B. Worden (London, 1978), p. 195. This edition by Worden contains only the first part of Ludlow's memoirs. I use Worden's edition for quotations from the 1660-1662 part of the text. Later quotes refer to Ludlow's manuscript, "A voyce from the watch tower", Oxford, Bodleian Library, MS Eng.hist.c.487 (hereafter "Voyce"). For a history of this text, see the introduction to Worden's edition and his "Whig History and Puritan Politics: The Memoirs of Edmund Ludlow Revisited", Historical Research 75 (2002), pp. 209-37.

23. See note 22 above.

24. Ludlow, "Voyce", p. 966.

25. Some very similar language can also be found in the eighth dialogue of Sidney's Court Maxims.

26. E.g. Ludlow, “Voyce”, p. 1072 (“tyrant"), and p. 1077, p. 1134 (“present Usurper").

27. Ludlow, "Voyce", p. 966.

28. Ralph C.H. Catterall, "Sir George Downing and the Regicides", American Historical Review 17 (1912), pp. 268-289.

29. See the author's “Les juges jugez, se justifiants (1663) and Edmund Ludlow's Protestant Network in Seventeenth-Century Switzerland”, Historical Journal 58:2 (2014), pp.1-28.

30. Ibid., pp. 10-11. For their religious refugee status see Raths-Manual der Stadt Bern, A II 454, vol. 143 (27 January 1662 to 7 June 1662). The original entry (in German) for 16 April, p. 317, reads: "Uff etlicher, von des Glaubens wegen, $\mathrm{u} \beta$ Ihrem Land vertribener Enggelländeren gebürendes Nachwerben, daß Sy sich so lang es Ir g[nädigen] h[erren] gefallen und sich wol verhalten werdend, alhier Inn Ihr g[nädigen] h[erren] Lands uffhalten und Ihre Sicherheit haben Mögind."

31. Ludlow, Voyce, p. 922. Louis XIV's younger brother, Philippe I, duke of Orléans (and duke of Anjou) was married to Princess Henrietta of England and Scotland, daughter of Charles I and sister of Charles II. The Duchess of Orléans/Anjou played an important role in the persecution of the regicides on the Continent. After several failed attempts on the lives of the exiles, John Lisle was finally assassinated in Lausanne in 1664. See Jean Hugli, “Les 'régicides' anglais et l'assassinat du chancelier Lisle (1664)" in Grandes heures de Lausanne (1041-1797): Ouvrage orné de 8 hors-texte et d'une vignette de couverture (Lausanne, 1967), chapter 7; the same, "Un drame à Lausanne en 1664", 
Rendez-vouz: Revue du Léman 10 (October 1948), n.p.; and Clive Holmes, "John Lisle, Lord Commissioner of the Great Seal, and the Last Months of the Cromwellian Protectorate", English Historical Review 122 (2007), pp. 918-36.

32. Algernon Sidney (from Rome?) to Robert earl of Leicester, $8 / 18$ April 1661, in Collins, Letters and memorials of state, vol. ii, pp. 708-10, p. 709.

33. Ibid., p. 710.

34. Ibid., p. 710.

35. Algernon Sidney from Rome to Robert earl of Leicester, 19/29 November 1660, in Collins, Letters and memorials of state, vol. ii, pp. 700-701, p. 700.

36. Algernon Sidney (from Rome) to Robert earl of Leicester, 22 April/2 May 1661, in Collins, Letters and memorials of state, vol. ii, pp. 716-7, p. 717.

37. Algernon Sidney from Frascati to Robert earl of Leicester, 23 June/3 July 1661, in Collins, Letters and memorials of state, vol. ii, pp. 720-1, p. 720.

38. Algernon Sidney (from Rome) to Robert earl of Leicester, 29 January/ 8 February 1660/1, in Collins, Letters and memorials of state, vol. ii, p. 704.

39. Algernon Sidney (from Rome) to Robert earl of Leicester, 22 April/2 May 1661, in Collins, Letters and memorials of state, vol. ii, pp. 716-7, p. 717.

40. This included the Act of Uniformity (1662), the Conventicle Act (1664) and the Five Mile Act (1665).

41. Being a good citizen and patriot can in some cases mean acting against one's own country David Held, "Cosmopolitanism, democracy and the global order" in Maria Roviso and Magdalena Nowicka (eds), The Ashgate Research Companion to Cosmopolitanism (Farnham, Ashgate, 2011), pp. 163-77, p. 170.

42. On the friendship between Sidney and Furly, see William Hull, Benjamin Furly and Quakerism in Rotterdam (Lancaster, Lancaster Press, 1941), pp. 77-82; and Luisa Simonutti, "English guests at 'De Lantaarn'. Sidney, Penn, Locke, Toland and Shaftesbury” in Sarah Hutton (ed.), Benjamin Furly 1646-1714: a Quaker Merchant and his Milieu (Firenze, Olschki, 2007), pp. 31-66. Sarah Hutton suggests (drawing on Richard Greaves) that Sidney's Court Maxims might have been produced at Furly's house. See her 'Introduction' to Hutton (ed.), Benjamin Furly, pp. 1-10, pp. 3, 4-5.

43. Algernon Sidney, Court Maxims, pp. 82-3. The manuscript of the Court Maxims was discovered at Warwick Castle in the 1970s by Blair Worden and subsequently edited for publication 1996. Sidney, Court Maxims, p. vii. Note that Sidney uses religious language similar to that of Ludlow. On Sidney's religion and politics, see Michael Winship, “Algernon Sidney's Calvinist Republicanism”, Journal of British Studies 49:4, 2010, pp. 753-773.

44. G(eorge) Van Santvoord, Life of Algernon Sidney: with sketches of some of his contemporaries and extracts from his correspondence and political writings, $3^{\text {rd }}$ ed. (New York, Charles Scribner, 1858), p. 181.

45. Ludlow, "Voyce", p. 1056.

46. Ibid., p. 1058.

47. Ibid., p. 1059.

48. Ibid., p. 1065.

49. Ibid., p. 1079.

50. Ibid., p. 1057.

51. Ibid., pp. 1056-7.

52. Van Santvoord, Life of Sidney, p. 182.

53. Ludlow, "Voyce", p. 1112.

54. Ibid., p. 1113.

55. Ibid., p. 922.

56. Scott, Algernon Sidney and the English Republic, p. 184; Ludlow, "Voyce”, p. 1123. 
57. 1 écu was worth 3 livres tournois. In today's money this might have been (very) roughly 1 million pounds.

58. Louis XIV, Mémoires pour les années 1661 et 1666, ed. J. Lognon (Paris, 1923), p. 213, quoted in Scott, Algernon Sidney and the English Republic, p. 184 (Scott's translation).

59. Scott, Algernon Sidney and the English Republic, p. 184.

\section{ABSTRACTS}

This article assesses the language and actions employed by English republicans in European exile during the 1660s and 1670s to conceptualise their transnational political and religious identity, their sense of citizenship, and their relationship to their home country. It argues that the republican exiles continued to see themselves as political actors on behalf of their country and their 'cause', if not necessarily of a specific government.

Cet article analyse le vocabulaire utilisé et les activités poursuivies par les républicains anglais durant les années 1660-1670, période de leur exil européen, pour conceptualiser leur identité politique et religieuse, leur concept de citoyenneté et leurs relations avec leur pays d'origine. La thèse soutenue est que les exilés républicains continuaient à se percevoir comme agents politiques au service de leur pays et de leur «cause », bien que n'étant pas nécessairement au service d'un gouvernement particulier.

\section{INDEX}

Mots-clés: Citoyenneté, républicanisme, exil; XVIIe siècle

Keywords: citizenship, republicanism, exile, seventeenth century 